\title{
A Comparative Study of DNA Extraction Method with and without Using Proteinase K Enzyme
}

\author{
Ishwar Prasad Dubey ${ }^{1,2}$, R.K. Kumawat ${ }^{3,4}$, Shivani Dixit ${ }^{2,3}$, Kamlesh Kaitholia ${ }^{2}$, \\ I.P. Tripathi ${ }^{1}$, Divya Shrivastava ${ }^{3}$, Pankaj Shrivastava ${ }^{2}$ \\ ${ }^{1}$ Faculty of Science and Environment, MGCGVV, Chitrakoot, Satna-485334, M.P, India, ${ }^{2}$ DNA Fingerprinting \\ Unit, State Forensic Science Laboratory, Sagar-470001, M.P, India, ${ }^{3}$ School of Life Sciences, Jaipur National \\ University, Jaipur-302017, Rajasthan, India, ${ }^{4}$ DNA Division, State Forensic Science Laboratory, Rajasthan, \\ Jaipur-302016, India
}

\begin{abstract}
Forensic DNA fingerprinting is the most believed method of the criminal investigation. With the advancement in technology, the method has become more and more sensitive and the technology now uses advanced method and new generation faster multiplex amplification systems. Most of these improvements in the technique are after the extraction of DNA. Despite automation in DNA extraction, still, the basic process of lysis of cells is an integral part of the analysis. We present here the comparison of DNA extraction results with and without using the proteinase k enzyme.
\end{abstract}

Keywords: DNA Extraction, Proteinase k, Forensic, DNA Fingerprinting.

\section{Introduction}

Deoxyribonucleic acid (DNA) based human identification is now accepted as the gold standard in forensics $^{(1)}$. It is recognized as the most convincing and practiced method in the criminal investigation since last two decades or more ${ }^{(2)}$. Forensic evidence collected from various crime scenes areanalyzed by the present-day forensic DNA technology using capillary electrophoresis (CE) technique ${ }^{(3)}$. The present-day DNA technology has faced many transformations to achieve the present state. With the advent of polymerase chain reaction (PCR), now it is possible to amplify even very minute quantities of DNA recovered from the crime scene in the detectable range ${ }^{(4)}$. The results of DNA testing on evidence samples are compared with the results of DNA analysis

\footnotetext{
Corresponding Author:

Pankaj Shrivastava

DNA Fingerprinting Unit, State Forensic Science

Laboratory, Sagar-470001, M.P, India

e-mail: pankaj.shrivastava@rediffmail.com;

Phone:+91-9424371946
}

of reference samples collected from known individuals. This power in the DNA technology was achieved with the development of the PCR based short tandem repeats (STRs) testing ${ }^{(1)}$ coupled with CE. DNA profiling is done using pre-formulated and pre-validated multiplex amplification kits ${ }^{(5),(6)}$ incorporating 15 to 27 markers. With the advancements in the technology, the multiplex kits used in forensic science are also improved not only in the number of markers in a single multiplex but also in the master mix, making the PCR faster ${ }^{(6)}$. Such analyses can link victims with suspects, other evidence items, or with a crime scene.

The forensic DNA technology is well developed, and now since the last decade, attempts are being made to make the technology faster and cheaper. There have been many attempts towards the direct amplification of forensic evidence ${ }^{(7),(8),(9)}$ including the launch of direct amplification kits for selected forensic samples by various manufacturers of multiplex kits. But still today, the standard method of DNA extraction using lysis buffer, sodium dodecyl sulfate (SDS) and proteinase $\mathrm{k}$ enzyme (PK) is widely accepted and most commonly used the technique in forensic DNA analysis because this technique is standardized with the whole variety of forensic samples. 
Normal forensic lysis buffer contains Tris $(\mathrm{pH}$ is maintained by HCL), EDTA ( $\mathrm{pH}$ is maintained by $\mathrm{NaOH}$ ) and $\mathrm{NaCl}$. Besides lysis buffer SDS (Sodium dodecyl sulfate) is the most commonly used strong anionic detergent, which has the capability, to disrupt the cell membrane by solubilizing proteins and lipids along with denaturing histones and other DNA binding proteins. Proteinase $\mathrm{k}$ is the second most important chemical used in DNA extraction, which helps in digesting proteins. This enzyme also deactivates nuclease enzymes, which degrades DNA in the process of DNA extraction. Proteinase $\mathrm{k}$ is a costly chemical, in comparison with the other chemicals used in the process of DNA extraction. With the advancement of present DNA technology, the requirement of input DNA is less than 500 picograms with all the new generation multiplex amplification systems (Table 1). We tested the routine DNA extraction protocol of lysis with and without using the proteinase k enzyme.

\section{Material and Method}

Twenty-five liquid blood samples received as a case exhibit at the DNA Fingerprinting unit of State Forensic Science Laboratory, Sagar, MP, India, were used for the study. All the samples were collected with written informed consent and as per the declaration of Helsinki ${ }^{(10)}$ for the DNA fingerprinting examination. The samples were transported to the laboratory under the ice and were preserved at $4^{\circ} \mathrm{C}$ till further processing. $600 \mu 1$ of each liquid blood sample was processed with the lysis buffer (namely forensic buffer) routinely used in forensic DNA examination of the laboratory.
To each sample, $600 \mu 1$ of forensic buffer (1 MTris pH 8 with HCL, 0.5 M EDTA pH 8 with $\mathrm{NaOH}$, and 5 $\mathrm{MNaCl}), 50 \mu \mathrm{l}$ of $20 \%$ SDS, and $10 \mu 1$ of PK $(20 \mathrm{mg} /$ $\mathrm{ml}$ ) was added. All the samples were also processed simultaneously without using PK. A forensic paternity examination was also processed using both approaches.

Extracted DNA was quantified using the PowerQuant ${ }^{\circledR}$ human DNA quantification kit (Promega, Madison, WI, USA/Promega) on Real-Time PCR 7500 machine (Thermo). Quantified DNAwas subjected to amplification for 15 autosomal Short Tandem repeats (as STRs) along with sex-determining Amelogenin marker using AmpFISTR ${ }^{\circledR}$ Identifiler ${ }^{\circledR}$ Plus PCR Amplification kit (Thermo) on ABI 9700thermal cycler (Thermo) as per the recommendation of the manufacturer except $10 \mu 1$ reaction volume was used. $1 \mu \mathrm{l}$ of amplified DNAwas diluted in the solution of $10 \mu \mathrm{H}$ HiDiFormamide and 0.2 $\mu 1 \mathrm{Liz} 500$. DNA fragments were separated using POP-4 and $36 \mathrm{~cm}$ capillary array onABI 3100 Genetic analyzer (Thermo) as per the recommended protocol of the manufacturer. Allelic Ladder provided along with the multiplex kit was used for the designation of the allele and obtained data was analyzed using Genemapper ${ }^{\circledR}$ software v3.5 (Thermo).

Findings: The results of DNA extraction from blood samples with and without using the proteinase k enzyme are presented in Figure 1.All the 25 samples processed with and without proteinase $\mathrm{k}$ enzyme yielded a good quantity of DNA. The yield of DNA without PK ranged 30 to $46 \mathrm{ng} / \mu \mathrm{l}$ and the yield of DNA with PK ranged 35 to $61 \mathrm{ng} / \mu \mathrm{l}$ (Figure 1).

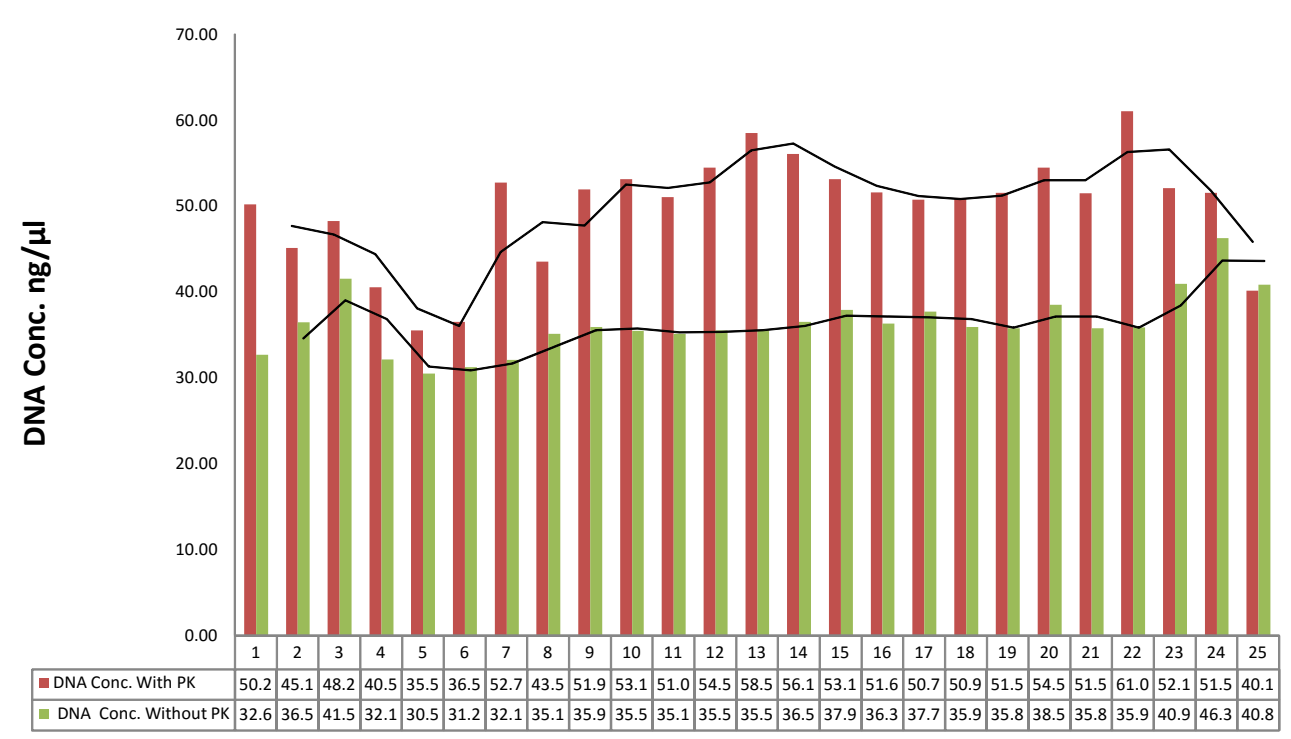

Figure 1: Quantity of DNA from blood samples 


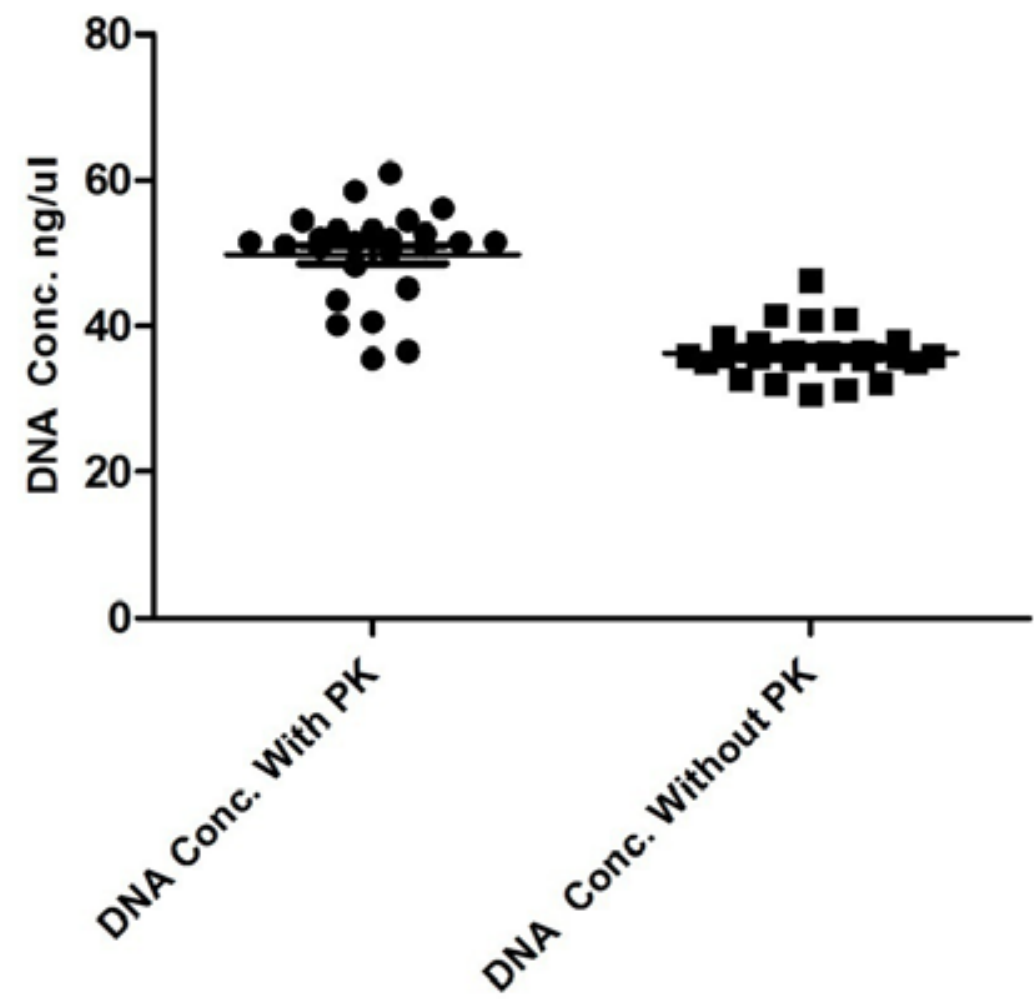

Figure 2: Statistical evaluation of obtained quantity of DNA from blood samples

Table 1: Statistical analysis of quantity of DNA from blood samples

\begin{tabular}{|l|c|c|}
\hline Number of values & $\mathbf{2 5}$ & $\mathbf{2 5}$ \\
\hline Minimum & 35.54 & 30.55 \\
\hline 25\% Percentile & 46.70 & 35.16 \\
\hline Median & 51.54 & 35.91 \\
\hline 75\% Percentile & 53.13 & 37.83 \\
\hline Maximum & 61.05 & 46.31 \\
\hline Mean & $\mathbf{4 9 . 8 7}$ & $\mathbf{3 6 . 3 4}$ \\
\hline Std. Deviation & 6.335 & 3.487 \\
\hline Std. Error & 1.267 & 0.6975 \\
\hline Lower 95\% CI of mean & $\mathbf{4 7 . 2 5}$ & $\mathbf{3 4 . 9 0}$ \\
\hline Upper 95\% CI of mean & 52.48 & 37.78 \\
\hline One sample t test & & \\
\hline Theoretical mean & 0.0 & 0.0 \\
\hline Actual mean & 49.87 & 36.34 \\
\hline Discrepancy & -49.87 & -36.34 \\
\hline 95\% CI of discrepancy & 47.25 to 52.48 & 34.90 to 37.78 \\
\hline t, df & $\mathrm{t}=39.36 \mathrm{df}=24$ & $\mathrm{t}=52.10 \mathrm{df}=24$ \\
\hline P value (two tailed) & $<0.0001$ & $<0.0001$ \\
\hline Significant (alpha $=0.05) ?$ & Yes & Yes \\
\hline
\end{tabular}

The mean value of DNA extracted using with proteinase $\mathrm{k}$ approach was 49.87 (Standard deviation=6.33) however the mean value of DNA extracted without using proteinase $\mathrm{k}$ approach was 36.33 (Standard deviation=3.48). The obtained results showed difference in the yield of DNA in both the approaches. However, as the need of DNA required for amplification using new generation multiplex kits are less than 500 picogram, hence the achieved quantity of extracted DNA sounds good enough for use in forensic DNA typing of samples which is expected to have a good amount of DNA.

We also present a case of sexual assault in which a lady was sexually assaulted and gave birth to a male child. The blood samples of suspect along with the samples of the victim and the newborn male child were received for establishment of paternity at State Forensic Science Laboratory, Sagar, MP, and India. DNA is extracted using both the approaches in this case of paternity establishment involving blood samples of the trio. The obtained results in the case using both the approaches are shown in Table 2. 
Table 2: DNA profile of Trio in a case of paternity establishment

\begin{tabular}{|l|c|c|c|}
\hline Genetic Markers & Father & Child & Mother \\
\hline D8S1179 & 10,13 & 10,14 & $30,33.2$ \\
\hline D21S11 & 28,28 & 28,30 & 10,11 \\
\hline D7S820 & 10,11 & 10,11 & 7,11 \\
\hline CSF1PO & 11,12 & 11,12 & 16,16 \\
\hline D3S1358 & 15,17 & 16,17 & 7,7 \\
\hline THO1 & 6,6 & 6,7 & 10,11 \\
\hline D13S317 & 10,11 & 10,11 & 9,12 \\
\hline D16S539 & 10,11 & 11,12 & 18,23 \\
\hline D2S1338 & 23,25 & 18,23 & 13,14 \\
\hline D19S433 & $15,15.2$ & 13,15 & 16,18 \\
\hline vWA & 16,18 & 16,18 & 8,9 \\
\hline TPOX & 8,11 & 8,11 & 14,17 \\
\hline D18S51 & 17,18 & 14,17 & 11,13 \\
\hline D5S818 & 12,12 & 12,13 & 22,24 \\
\hline FGA & 23,26 & 23,24 & $X X$ \\
\hline AMELOGENIN & $X Y$ & $X Y$ & \\
\hline
\end{tabular}

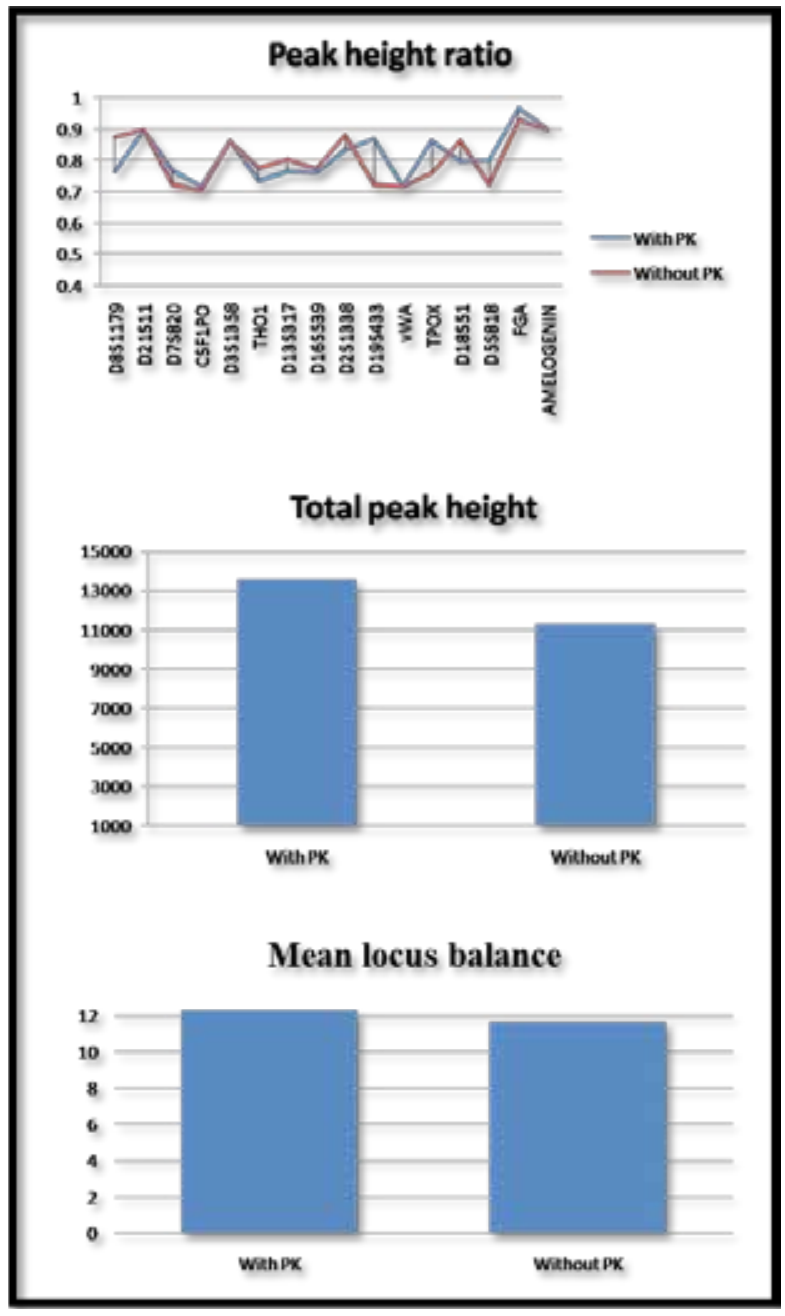

Figure 3: DNA profile quality parameters in the same case of paternity 
The child showed a perfect trio match with both the parents using both the approaches and same results were obtained. The DNA profile observed using both the approaches showed the concordance. DNA profile quality measures, namely peak height ratio, total peak height and mean locus balance were also compared (Figure 4). The compared profile quality parameters also showed the suitability of both the approaches for forensic DNA typing work using blood samples.

The compared profile quality parameters also showed the suitability of both the approaches for forensic DNA typing work using blood samples. As blood contains comparatively higher amount of DNA, hence we recommend this approach to be used for all the samples which has good amount of DNA. However with other range of forensic samples which has comparatively lower amount of DNA, this approach needs to be further evaluated.

\section{Conclusion}

The yield of DNA varied with and without the use of proteinase $\mathrm{k}$, but a good quantity of DNA was extracted using both the approaches. The yield of obtained DNA without proteinase $\mathrm{k}$ was sufficient enough to be used in today's forensic DNA testing, as the requirement of DNA in present-day DNA testing is less than 1ng. This study is useful for forensic DNA typing as well as human genetics and anthropological studies concerning high-quality DNA extraction.

Conflict of Interest: Authors declared that they have no conflict of interest.

\section{Source of Funding: None}

Ethical Clearance: This study was approved by the Institutional Ethical Committee of the Jaipur National University, Jaipur vide letter no. JNUMSRC/ IEC/2018/45 dated 20.07.2018.

Acknowledgements: Authors acknowledge the support and motivation from Director, State Forensic Science Laboratory, Sagar, MP, India.

\section{Reference}

1. Butler JM. Forensic DNA typing: biology, technology, and genetics of STR markers. Elsevier; 2005.

2. Shrivastava P, Jain T, Trivedi VB. A genetic portrait of Oraon Indian tribe drawn with 15 autosomal and 17 Y chromosomal STR markers. Int J Legal Med. 2016;130(5):1185-6.

3. Roewer L. DNA fingerprinting in forensics: past, present, future. Investig Genet. 2013;4(1):22.

4. Mullis K, Faloona F, Scharf S, Saiki RK, Horn GT, Erlich H. Specific enzymatic amplification of DNA in vitro: the polymerase chain reaction. In: Cold Spring Harbor symposia on quantitative biology. Cold Spring Harbor Laboratory Press; 1986. p. 263-73.

5. Shrivastava P, Jain T, Trivedi V Ben. DNA fingerprinting: A substantial and imperative aid to forensic investigation. Eur $\mathrm{J}$ Forensic Sci. 2016;3:23.

6. Dash HR, Shrivastava P, Mohapatra BK, Das S. DNA Fingerprinting: Advancements and Future Endeavors. Springer; 2018.

7. Caputo M, Bobillo MC, Sala A, Corach D. Optimizing direct amplification of forensic commercial kits for STR determination. J Forensic Leg Med. 2017;47:17-23.

8. Wang DY, Chang C-W, Oldroyd NJ, Hennessy LK. Direct amplification of STRs from blood or buccal cell samples. Forensic Sci Int Genet Suppl Ser. 2009;2(1):113-4.

9. Garcia-Palacios MP, Martínez-Gómez J, Gomes C, Palomo-Díez S, Arroyo-Pardo E, Esteban-Ramos V. A new strategy for a "direct" amplification of forensic samples. Forensic Sci Int Genet Suppl Ser. 2017;6:e560-1.

10. Rickham PP. Human experimentation. Code of ethics of the world medical association. Declaration of Helsinki. Br Med J. 1964;2(5402): 177. 